\title{
Effects of Ethical Certification and Ethical eWoM on Talent Attraction
}

\author{
Victoria-Sophie Osburg ${ }^{1} \cdot$ Vignesh Yoganathan $^{2}$ (I) $\cdot$ Boris Bartikowski ${ }^{3} \cdot$ Hongfei Liu $^{4} \cdot$ Micha Strack $^{5}$
}

Received: 10 February 2018 / Accepted: 12 September 2018 / Published online: 20 September 2018

(c) The Author(s) 2018

\begin{abstract}
Whilst previous studies indicate perceived company ethicality as a driver of job seekers' job-pursuit intentions, it is poorly understood how and why ethical market signals actually affect their application decisions. Perceptions of company ethicality result from market signals that are either within the control of the company (e.g. ethical certifications) and from market signals that are beyond the company's control (e.g. ethical eWoM). Building on communication and information processing theories, this study therefore considers both types of ethical market signals, and examines the psychological mechanisms through which they affect job seekers' intention to apply for a job. The results from a controlled online experiment show that both types of ethical market signals increase job seekers' job-pursuit intentions. These relationships are mediated by applicants' attitude towards the job advertisement, their perceptions of corporate employment image and self-referencing. Consequently, the present study alerts practitioners to consider the effects of company-controlled and non-company-controlled ethical market signals, particularly when aiming to recruit highly-qualified millennial candidates.
\end{abstract}

Keywords Ethical certifications $\cdot$ Ethical eWoM $\cdot$ Millennial employment $\cdot$ Job-pursuit intentions

Vignesh Yoganathan

vj.yoganathan@gmail.com

Victoria-Sophie Osburg

V.Osburg@hull.ac.uk

Boris Bartikowski

boris.bartikowski@kedgebs.com

Hongfei Liu

hongfei.liu@essex.ac.uk

Micha Strack

mstrack@uni-goettingen.de

1 Hull University Business School, University of Hull, Cottingham Road, Hull HU6 7RX, UK

2 School of Management, University of Bradford, Emm Lane, Bradford BD9 4JL, UK

3 KEDGE Business School, Domaine de Luiny, Rue Antoine Bourdelle, 13009 Marseille, France

4 Essex Business School, University of Essex, Wivenhoe Park, Colchester CO4 3SQ, UK

5 University of Goettingen, Gosslerstrasse 14, 37073 Goettingen, Germany

\section{Introduction}

Companies aim at recruiting the most promising talents through measures such as financial incentives, career development programmes or flexible working hours. Another talent-attracting factor is company ethicality, i.e. the extent to which job seekers perceive a company acts responsibly towards the environment and society (Lin et al. 2012; Vlachos et al. 2013; Wang 2013). Almost half of UK's workforce prefers to work for ethical companies (Jenkin 2015). Company ethicality is most important for millennials (Solomon 2016) and highly educated candidates (Tsai et al. 2014; Wang 2013). Extant research indicates that company ethicality results from cues or market signals that job seekers mentally process (e.g. Tsai et al. 2014; Zerbini 2017). Such market signals vary in how successful they are in making ethical criteria decision-relevant (Osburg et al. 2017). However, how and why different types of ethical market signals affect job seekers' job-pursuit intentions is poorly understood. Zerbini (2017, p. 13) recently emphasised that studies considering multiple ethical market signals are "lacking in business ethics research" and calls for more research to unveil signalling outcomes in labour markets, considering other outcomes than employer attractiveness. 
To heed this call, we focus on job-pursuit intention as the outcome variable to explain and consider multiple ethical market signals. In particular, we differentiate two types of ethical market signals, ethical certifications in job advertisements and electronic Word-of-Mouth (eWoM) about company ethicality. Ethical certifications, such as Ethisphere (http://www.ethisphere.com) or B Corporation (http:// www.bcorporation.com) are widely recognised as signals of trust and sound company behaviour that affect perceptions of company ethicality (e.g. Zerbini 2017). On the other hand, eWoM (i.e. social media discussion about company ethicality that job seekers gather from platforms such as LinkedIn, Glassdoor or XING) is increasingly considered as an indispensable source of information for nowadays job seekers; particularly the technologically affine millennials rely on eWoM to gather job-relevant information (Frasca and Edwards 2017; Lee et al. 2013; Rutter et al. 2016).

The two considered types of ethical market signals differ with respect to the extent to which they are under a company's control. Firms can control the inclusion of ethical certifications in job advertisements (hence, 'company-controlled'), whereas ethical eWoM can hardly be controlled (hence, 'non-company-controlled'), suggesting that both types of signals should be considered for a better understanding of what motivates job seekers' pursuit intentions (cf., Eberle et al. 2013). For example, Rutter et al. (2016) argue that job seekers perceive ethical eWoM as a verification of a company's credentials, as the latter is provided independently from the organisation. However, no study before has investigated the combined effects of company-controlled (ethical certifications) and non-company-controlled (ethical eWoM) ethical market signals on job seekers' pursuit intentions. This is a surprising gap in the literature, not at least because employers and recruiters would benefit from insights that elucidate how these different types of ethical market signals operate to attract talents.

In addition, it is important to understand the psychological mechanisms through which company-controlled and non-company-controlled ethical market signals operate to affect job-pursuit intentions. We therefore build on communication and information processing theories, namely MacKenzie et al.'s (1986) Dual Mediation Hypothesis, Spence's (1973) Signaling Theory and Petty and Cacioppo's (1986) Elaboration Likelihood Model to develop a conceptual model that considers job seekers' attitude towards the job ad, corporate employment image and self-referencing as mediating variables in the relationship between multiple ethical market signals and job-pursuit intentions. We derive hypotheses from these theories and test them experimentally with data collected from millennial job seekers in the UK. The empirical results show significant differences in the effects of company-controlled and non-company-controlled ethical signals on job-pursuit intentions and support the proposed mediation mechanisms with important implications for theory and practice.

We contribute to the existing literature on employer attractiveness and job seeker behaviour in several ways. First, we provide evidence for the relevance of ethical market signals as antecedents of job seekers' job-pursuit intentions. Second, we demonstrate the importance of differentiating between company-controlled (i.e. ethical certification) and non-company-controlled (i.e. positive ethical eWoM) ethical market signals. Third, we uncover three different mediating mechanisms in the relationship between ethical market signals and job-pursuit intentions, thereby offering new insights into how and why ethical market signals take effect.

The remainder is organised as follows: we first present a review of relevant background literature on company ethicality, employer attractiveness and eWoM. We then develop our conceptual model and related hypotheses. Next, we present the particulars of our experimental study and the results of the hypotheses tests. Finally, we discuss the theoretical and managerial implications of our findings.

\section{Attracting Talents and Company Ethicality}

A vital part of recruitment processes is to attract applicants' attention and increase their interest to pursue with a job application (Tsai et al. 2014; Wang 2013). In their meta-analysis, Chapman et al. (2005) show that company attractiveness depends on five factors as perceived by job applicants: characteristics of the job and organisation (e.g. payment, work type and environment, company size and familiarity), behaviour of the recruiter, the recruitment process, person-organisation fit and expectations to be hired. The first factor, characteristics of the job and organisation, includes job seekers' perceptions of company ethicality, hence their perceptions of the company's economic, environmental and social performance (e.g. Al-Tuwaijri et al. 2004; Lin et al. 2012; Tsai et al. 2014). Economic performance is associated with good working environments, development opportunities and sustainable competitive advantage (Tsai et al. 2014). Environmental performance refers to the organisation's environmental impact, such as environmental pollution, waste management or eco-friendly production processes (Al-Tuwaijri et al. 2004). Social performance indicates the extent of the company's social welfare orientation, and how the organisation treats and supports its employees (e.g. equal opportunities) (Lin et al. 2012). As such, company ethicality contributes to building a good corporate employment image and, therefore, consists a sustained competitive advantage with positive impact on the recruitment, the development and the retention of employees (Lin et al. 2012; Stewart et al. 2011). 


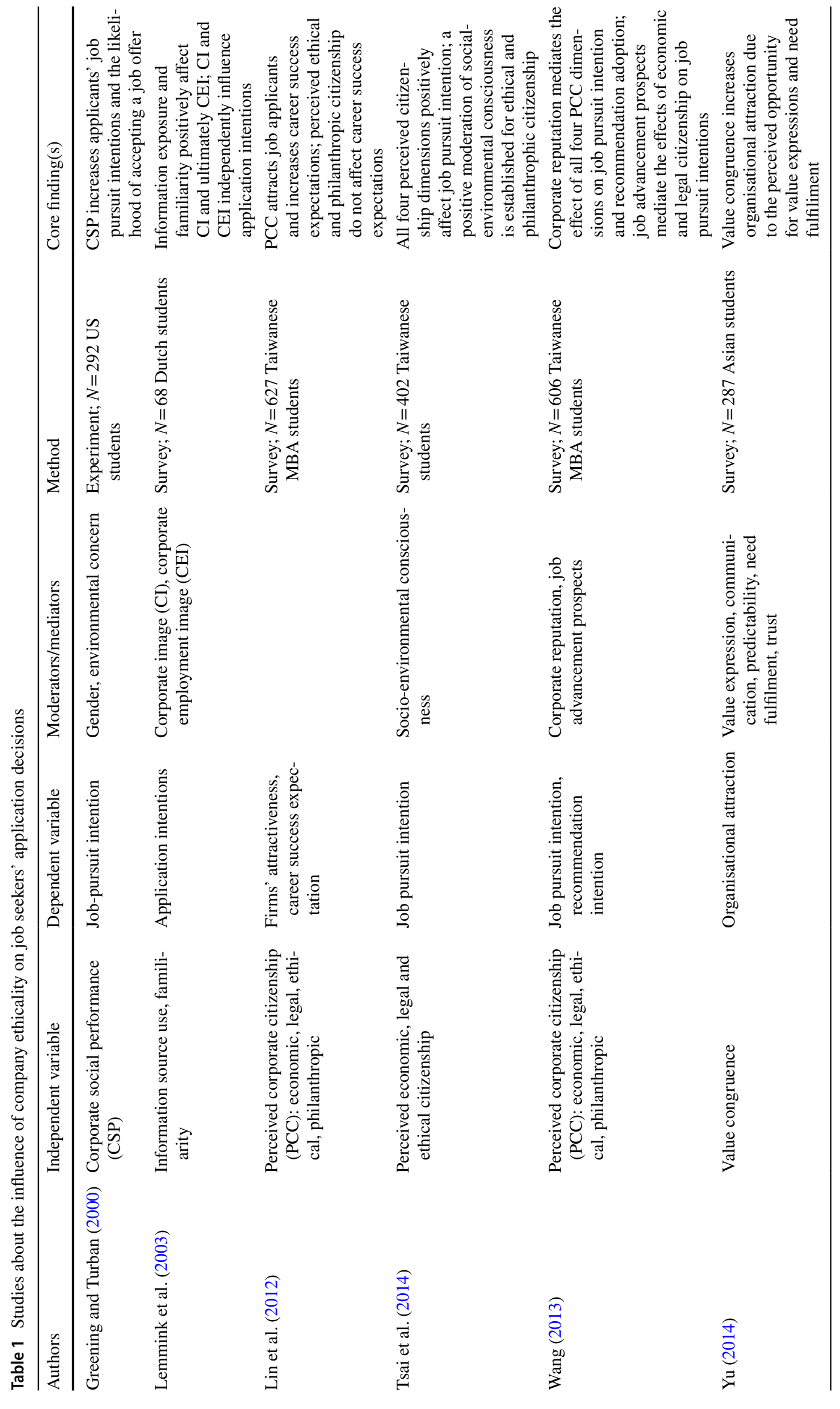


Fig. 1 Conceptual model

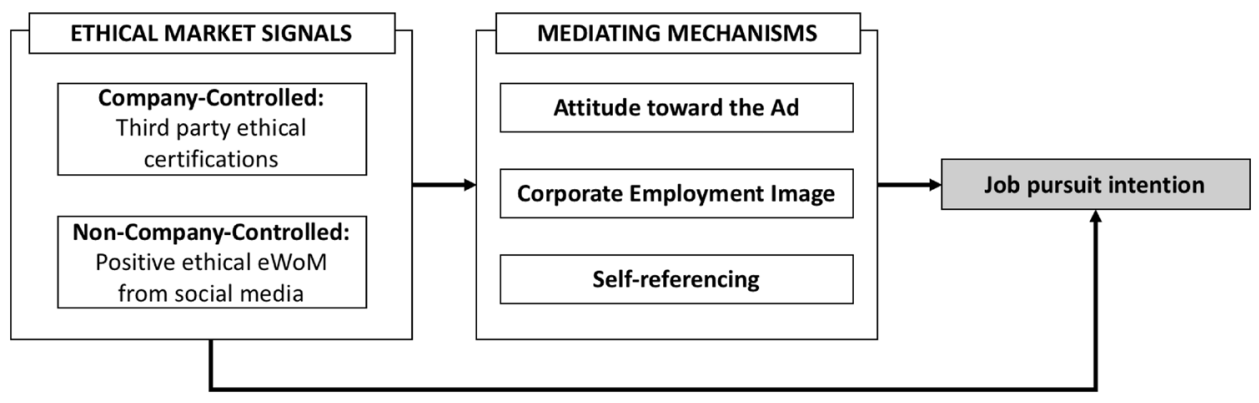

Table 1 provides an overview of empirical studies that explore the influence of company ethicality on talent attraction. While the existing literature indicates positive effects of company ethicality, particularly for millennials (e.g. Solomon 2016), they do not clarify how different types of ethical market signals operate to affect job seekers' perceptions about company ethicality and ensuing job-pursuit intentions. Moreover, most of the existing studies employ cross-sectional designs and may, therefore, not provide definite information about cause-and-effect relationships between company ethicality and job seeker behaviour. The present study addresses these gaps by experimentally investigating how two types of ethical market signals (ethical certifications and ethical eWoM) affect job seekers' pursuit intentions. Our experimental design simulates actual job application scenarios, which is more appropriate for testing causal hypotheses than observational designs. Moreover, we develop insights into the psychological mechanisms that account for the relationship between ethical market signals and pursuit intentions by considering relevant mediator variables.

\section{Theoretical Developments}

The conceptual model that guides the subsequent theoretical developments appears in Fig. 1. Drawing from previous literature, we hypothesise that ethical market signals in the form of third-party ethical certifications and positive ethical eWoM from social media act as antecedents of job seekers' pursuit intentions. We further expect that job seekers' attitude toward the ad, their perceptions of corporate employment image and self-referencing mediate the relationships between ethical market signals and pursuit intention.

\section{Effects of Ethical Market Signals on Job-Pursuit Intentions}

Signaling theory helps to understand how job seekers' decisions to respond to job advertisements are driven by the information they receive about potential target employers (Celani and Singh 2011; Rynes 1991; Spence 1973). Following this theory, job seekers aim at reducing information asymmetries between the organisation and themselves in order to infer the quality of the offering and inform their application decisions. Information asymmetry reduction is most relevant when signal-recipients have limited information about the target, such as typically in job application processes (e.g. Kirmani and Rao 2000; Spence 1973). Job seekers commonly combine signals about company ethicality from various sources to complement and consolidate their perceptions of the company and its actions (cf., Celani and Singh 2011; Srivastava and Lurie 2001). These include signals that may be controlled by the company (here: the disclosure of ethical certificates in job ads) and signals that cannot be controlled by the company (here: positive eWoM about company ethicality). Regardless of its source (company-controlled or non-company-controlled), positive information about company ethicality may signal good working conditions, career development opportunities, sustainable job advantages as well as social and environmental wellbeing (Greening and Turban 2000; Lin et al. 2012) and may therefore motivate job seekers to engage.

\section{Company-Controlled Signals about Company Ethicality}

Research has repeatedly shown that third-party ethical certifications serve as effective signals of ethical company behaviour in different contexts (Bradu et al. 2014). For example, studies show that ethical certifications enhance consumers' attitudes and trust toward the firm and its products (Aiken and Boush 2006; Vecchio and Annunziata 2015). We likewise expect that third-party ethical certifications in job advertisements serve as positive signals that motivate job seekers' job-pursuit intentions.

H1a Job advertisements with third-party ethical certifications, as compared to job advertisements without such certifications, enhance job-pursuit intentions.

\section{Non-Company-Controlled Signals about Company Ethicality}

Job seekers also rely on third-party information about company ethicality that is not under direct control of firms. 
Social media are quintessential in this respect, particularly in relation to graduate jobs and for the technologically affine millennials (Frasca and Edwards 2017; Rutter et al. 2016). eWoM from social media platforms such as LinkedIn, Glassdoor or XING typically involves written comments that current or previous employees make about their company (cf., Bi et al. 2017). Paulin et al. (2006) suggest that WoM from experienced employees' offers job seekers valuable insights into the company and its working conditions. Similarly, Rutter et al. (2016) argue that social media endorsements have a verification function and may therefore bias job seekers pursuit intentions. Hence, eWoM represents another market signal that candidates may consider when deciding to apply for a job. In line with Signaling Theory (Rynes 1991; Spence 1973), we expect that positive eWoM about company ethicality, as compared to neutral eWoM, serves as an important market signal that motivates job-pursuit intentions.

H1b Positive ethical eWoM, as compared to neutral eWoM, enhances job seekers' pursuit intentions.

\section{Mediating Mechanisms between Ethical Market Signals and Job-Pursuit Intentions}

Alongside their direct impact, it is also important to unveil the psychological mechanisms through which ethical market signals affect job seekers' pursuit intentions for a better understanding of how companies may attract talents. Building on MacKenzie et al.'s (1986) Dual Mediation Hypothesis, Spence's (1973) Signaling Theory and Petty and Cacioppo's (1986) Elaboration Likelihood Model, we consider three mediating variables: attitude toward the job ad, corporate employment image and self-referencing, as illustrated in Fig. 1.

\section{Attitude toward the Ad}

The Dual Mediation Hypothesis (MacKenzie et al. 1986) highlights that attitude toward the ad is crucial for achieving advertising effectiveness. Through testing competing frameworks about the causal relationships, MacKenzie et al. (1986) show that attitude toward the ad acts as a core mediator between cognitions about the ad and the brand, as well as attitude toward the brand and ultimately purchase intensions. Accordingly, Bickart and Ruth (2012) found that environmental labels increase consumers' purchase intention through more favourable attitudes towards the ad. Extending the attitude toward the ad model, Goldsmith et al. (2000) show that the credibility of a source, when verified by another entity (i.e. a third-party), influences attitude toward the ad, and ultimately purchase intentions. Similarly, we expect that independent ethical certifications displayed in job ads enhance job seekers' attitude toward that ad. Following Cheung and Thadani (2012), attitude changes are among the most frequently confirmed consequences of eWoM provision. Hence, positive ethical eWoM may foster positive attitudes towards the ad because eWoM serves as a third-party verification of organisational information (Rutter et al. 2016). We consequently expect that independent endorsements of company ethicality (i.e. ethical certifications or ethical eWoM) lead to enhanced pursuit intentions because of their positive impact on attitude toward the ad.

H2 Attitude toward the ad mediates the effects of third-party ethical certifications (H2a) and positive ethical eWoM (H2b) on job seekers' pursuit intentions.

\section{Corporate Employment Image}

While general corporate image or reputation may vary significantly between different stakeholder groups, corporate employment image is a more specific construct that embraces the perceptions of current employees and potential applicants (Lemmink et al. 2003). Corporate employment image determines the attractiveness of organisations for job seekers across industries (Cober et al. 2003; Tsai and Yang 2010; Turban 2001) and is vital to increase job seekers' application intentions, particularly among highly-qualified candidates (Kim et al. 2011; Lemmink et al. 2003). Previous research also reveals a close relationship between a company's ethicality and corporate employment image (Riordan et al. 1997). For example, Tsai et al. (2014) emphasise that job applicants expect organisations to abide ethical standards and norms.

In line with Signaling Theory (Rynes 1991; Spence 1973) we expect that ethical market signals affect job seekers' jobpursuit intentions not only directly (H1), but also indirectly through the firms' corporate employment image. Hence, ethical market signals (ethical certificates in job ads or ethical eWoM) may serve to reduce information asymmetries among job seekers and positively affect their perceptions of corporate employment image which, in turn, informs their application intentions. We accordingly expect that corporate employment image mediates the positive effect of ethical market signals on job seekers' job-pursuit intentions.

H3 Corporate employment image mediates the effects of third-party ethical certifications (H3a) and positive ethical eWoM (H3b) on job seekers' pursuit intentions.

\section{Self-Referencing}

The Elaboration Likelihood Model (Petty and Cacioppo 1986) states that attitude change is attributable to how people process information. Faced with a persuasive message, people engage in higher or lower levels of elaboration of 
the message, the so-called central and peripheral routes of persuasion (Petty and Cacioppo 1986). Information that is perceived as personally more relevant tends to encourage deeper processing, and more relevant positive information will therefore lead to more positive reactions in relation to that information (Burnkrant and Unnava 1989; Petty and Cacioppo 1986). Individual or situational factors may shape this process. As such, information that people can personally better connect with tends to be perceived as more relevant and encourages deeper elaboration (Kahle and Homer 1985; Kang and Herr 2006; Yoon and Park 2012).

This points to the importance of considering self-referencing as a third mediator variable in the relationship between ethical market signals and job-pursuit intentions. Self-referencing is "a process inducing relative significance where a consumer relates message information to his or her self-experience or expectation" (Burnkrant and Unnava 1989, p. 632). In turn, the similarity or congruence between a stimulus and an individual affects persuasion positively (Wheeler et al. 2005; Yoon and Park 2012). Layton and Insko (1974, p. 149) called the similarity effect "one of the best documented generalizations in social psychology". For example, Martin et al. (2004) showed that higher purchase intentions result if individuals identify with the person endorsing a product in an advertisement. Hence, job ads that enhance self-referencing enable people to better connect with the ad, leading to deeper elaboration, and ultimately more favourable job-pursuit intentions. Since nowadays job applicants, especially the millennial generation, increasingly value ethical principles as part of their self-concept (Solomon 2016), it is conceivable that ethical certifications in job ads and positive eWoM about company ethicality increase self-referencing which, in turn, leads to enhanced job-pursuit intentions.

H4 Self-referencing mediates the effects of third-party ethical certification $(\mathrm{H} 4 \mathrm{a})$ and positive ethical eWoM $(\mathrm{H} 4 \mathrm{~b})$ on job-pursuit intention.

\section{Study}

\section{Pre-study}

A preliminary qualitative study was conducted with 31 postgraduate students who were asked to discuss several themes in relation to company ethicality: what they thought of as an 'ethical employer', what it takes to identify an organisation as an ethical employer, what relevant 3rd party ethical certifications an employer could obtain/achieve, and the relevance of such 3rd party certifications for job application decisions. Social media and word-of-mouth information, as well as the importance of identifying with job postings emerged as prominent drivers of their willingness to apply for a job. Moreover, the results suggest that Ethisphere and B Corporation were seen as relevant 3rd party certifications and were, therefore, selected as experimental stimuli in the main study.

\section{Experimental Design}

The experiment relied on a 2 (company-controlled market signals: ethical certification vs. no certification) $\times 2$ (noncompany-controlled market signals: positive ethical eWoM vs. neutral ethical eWoM) mixed-factorial design. Companycontrolled market signals were varied between subjects and non-company-controlled market signals were varied within subjects (randomly assigned). Participants were asked to imagine that they are searching for a graduate job online, and that they found the job adverts of two fictive companies.

The mock job adverts shown to the respondents differed regarding the inclusion of ethical certifications (with vs. without certification) and a LinkedIn eWoM endorsement (positive vs. neutral) related to the company's ethicality. ${ }^{1}$ Based on the results of the pre-study, we used B Corporation and Ethisphere as ethical certifications. ${ }^{2} \mathrm{~B}$ Corporation (2017) is issued by an international non-profit organisation and certifies around 1000 businesses worldwide that meet a large range of social and environmental criteria. Similarly, Ethisphere (2017) provides a list of 131 businesses, which represent the world's most ethical companies by considering a company's ethical business standards and practices, its promotion of managers and employees and implementation of best practices for the industry. We chose LinkedIn to mimic eWoM endorsements since this platform constitutes a widely preferred social media network for job hiring (Melanthiou et al. 2015). We contrasted positive ethical eWoM with neutral ethical eWoM in order to assess the effect of ethicality endorsements (and not a pure social media effect, as it would emerge when presenting no eWoM as the reference condition).

\section{Data Collection}

We conducted data online from 265 students in the UK who were about to apply for a job or were already in the job application process. Respondents' mean age was 26.68 years

\footnotetext{
${ }^{1}$ Stimuli are available on request.

2 Job advertisements may include a range of certifications, which are related to ethical criteria (e.g. Athena SWAN (ECU 2018) for gender equality in science and research, Disability Confident (2018) for companies committed to hiring applicants with disabilities). B Corporation and Ethisphere were selected for this study as they cover a full range of ethical criteria.
} 
Table 2 Job-pursuit intention models

\begin{tabular}{|c|c|c|c|c|c|c|c|}
\hline Model & M0 & M1 & M2 & M3 & M3a & M3b & M3c \\
\hline Intercept & 4.79 & 4.79 & 4.79 & 4.79 & 4.79 & 4.79 & 4.79 \\
\hline Certificate (L2) & & $0.18 *(0.02,0.33)$ & & -0.02 & 0.07 & -0.01 & 0.02 \\
\hline eWoM (L1) & & $0.35 * * *(0.26,0.43)$ & & $-0.06^{\dagger}$ & $0.10^{* *}$ & 0.01 & $0.08^{*}$ \\
\hline Certificate $\times$ eWoM $(\mathrm{L} 2 \times \mathrm{L} 1)$ & & -0.02 & & 0.01 & -0.04 & 0.02 & 0.01 \\
\hline $\mathrm{AD}$ attitude $\mathrm{L} 2$ & & & $0.21 * * *$ & $0.22 * * *$ & $0.80 * * *$ & & \\
\hline $\mathrm{AD}$ attitude $\mathrm{L} 1$ & & & $0.32 * * *$ & $0.33 * * *$ & $0.73 * * *$ & & \\
\hline Corp. emp. image L2 & & & $0.23 * * *$ & $0.23 * * *$ & & $0.92 * * *$ & \\
\hline Corp. emp. image L1 & & & $0.33 * * *$ & $0.38 * * *$ & & $0.84 * * *$ & \\
\hline Self-ref. L2 & & & $0.71 * * *$ & $0.71 * * *$ & & & $0.93 * * *$ \\
\hline Self-ref. L1 & & & $0.47 * * *$ & $0.49 * * *$ & & & $0.85 * * *$ \\
\hline Var bSs & 1.06 & 1.06 & 0.28 & 0.29 & 0.76 & 0.62 & 0.30 \\
\hline Var wSs & 1.29 & 1.15 & 0.46 & 0.46 & 0.67 & 0.68 & 0.60 \\
\hline ICC & 0.45 & & & & & & \\
\hline AIC & 1903 & 1856 & 1328 & 1339 & 1630 & 1599 & 1442 \\
\hline BIC & 1912 & 1864 & 1337 & 1348 & 1638 & 1608 & 1450 \\
\hline
\end{tabular}

Raw b coefficients are reported in brackets at the $95 \% \mathrm{CI}$; variance between subjects (bSs) and within subjects (wSs) allow to calculate the intra class correlation ICC in M0. Mediators included at both levels according to the CWC(M) procedure. AIC and BIC assess global misfit; the smaller the value, the better the model fit

$* * * p_{2 \mathrm{t}}<0.001, * * p_{2 \mathrm{t}}<0.01,{ }^{*} p_{2 \mathrm{t}}<0.05,{ }^{\dagger} p_{2 \mathrm{t}}<0.10$

$(\mathrm{SD}=6.66)$ and $43.8 \%$ of the participants were male. The selection of mostly millennials allowed us to focus on a generation with a strong preference for ethical company features (Jenkin 2015) and a high use of social media in the recruitment context (Rutter et al. 2016).

The variables of interest were measured with established scales that we adapted to the context (Table 3 in Appendix 1): Attitude toward the ad (Bickart and Ruth 2012) and corporate employment image (Riordan et al. 1997) were assessed with 7-point bipolar adjective items; self-referencing (Yoon and Park 2012) and job-pursuit intention (Wang 2013) were measured with 7-point rating scales. Descriptives and correlations are shown in Table 4 in Appendix 2. Respondents answered all scales after exposure to the experimental conditions. Additionally, manipulation checks were conducted to test the successful manipulation of the four conditions. Participants who failed to answer the manipulation check questions correctly were excluded from subsequent analyses.

\section{Results}

Because one of the conditions (ethical eWoM) was nested in participants, a two-level analysis was conducted using generalised linear mixed model procedure in IBM SPSS Statistics 24. In the multi-level approach, modelling is done stepwise: The M0 models show a large portion of individual variance in the DV (ICC 45\%, see last two rows in Table 2) as well as in the three mediators (attitude toward the ad ICC $32 \%$; corporate employment image ICC $35 \%$; self-referencing ICC 53\%; Table 4 in Appendix 2); thus, legitimising the multilevel approach. The experimental factors were effect coded and tested in model M1 (Table 2) for their direct effects. Job-pursuit intention was significantly higher for companies with ethical certifications (estim. 4.97) than for companies without ethical certifications $\left(4.61 ; t=2.23, p_{2 \mathrm{t}}=0.026\right)$. Additionally, job-pursuit intention also increased with a positive ethical eWoM (5.41) compared to a neutral one (4.44; $t=7.74, p_{2 \mathrm{t}}<0.001$ ). Hence, $\mathrm{H}_{1}$ and $\mathrm{H}_{3}$ were accepted (see Fig. 2). Ethical certifications did not mitigate the effect of eWoM or vice versa, although the negative sign pointed to a compensatory trend $\left(b=-0.02 ; t=-0.37, p_{2 \mathrm{t}}=0.714\right)$.

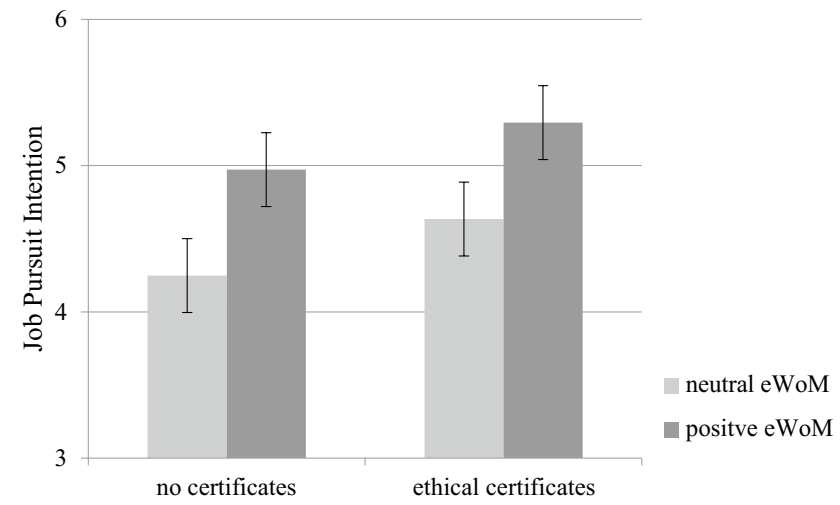

Fig. 2 Estimated means for the experimental conditions (95\% CI) 
In order to test for mediation, model M1 was also fitted to the three mediators, which led to very similar results (see: Table 5 in Appendix 3): both main effects reached significance and the interaction remained zero. Hence, $\mathrm{H}_{1 \mathrm{a}}$ and $\mathrm{H}_{1 \mathrm{~b}}$ are both supported.

To test for indirect effects of the experimental factors on job-pursuit intention, the $\mathrm{CWC}(\mathrm{M})$ procedure was applied following Zhang et al. (2009): in order to not confound level 1 Mediator-DV relations for the certification effect and level 2 Mediator-DV relations for the eWoM effect, the mediators have to be "Centered Within Context with reintroduction of the subtracted Means at Level 2" (CWC(M)). Thus, mediators appear twice in the prediction of the DV in models M2 and M3 (Table 2): once at the level of the individual L2 ("reintroduced mean", and globally centered with the means from Table 4 in Appendix 2) and again at the stimulus level L1 centred within individual. Results show a strong increase of model fit for M2 (e.g. compared with $\mathrm{AIC}=1903$ in M0, AIC declines in M2-1328) and all mediators reached significant b-coefficients at both levels $\left(t>3.38, p_{2 \mathrm{t}}=0.001\right)$.

Further, Model M3 in Table 2 tests for a complete mediation (Baron and Kenny 1986) or an indirect-only mediation in the terms of Zhao et al. (2010). The results prove that the mediators jointly explain why ethical certifications and positive ethical eWoM increase job-pursuit intention; both experimental factors did not further add to a joint prediction, instead model fit declined (i.e. AIC and BIC incline from $\mathrm{M} 2$ to $\mathrm{M} 3$, thus penalising redundant predictors). Using adequate slopes from M3 (and from the IV-mediator relations, Table 5 in Appendix 3), indirect effects of ethical certifications at L2 (Sobel's $z=1.92,2.46,2.44$ for attitude toward the ad, corporate employment image and self-referencing at $\mathrm{L} 2$ respectively) and positive ethical eWoM at L1 $(z=4.71$, $4.95,5.76$ ) were established. Hence, $\mathrm{H}_{2 \mathrm{a}}, \mathrm{H}_{2 \mathrm{~b}}, \mathrm{H}_{3 \mathrm{a}}, \mathrm{H}_{3 \mathrm{~b}}, \mathrm{H}_{4 \mathrm{a}}$ and $\mathrm{H}_{4 \mathrm{~b}}$ were all accepted.

We also checked if a single mediator was able to completely mediate the experimental factors alone (M3a-M3c). Results are mixed: although ad attitude profits from positive ethical eWoM (see: Table 5 in Appendix 3) and the indirect effect of positive ethical eWoM via ad attitude at L1 from M3a reached Sobel's $z=7.29$, a small but significant direct effect of eWoM remained in M3a. Corporate employment image, however, completely mediates both IV. In terms of robustness, the inclusion of all three mediators at both levels in model M2 with its best fit resembles the proposed model.

\section{Discussion and Conclusion}

Recruiting and retaining capable employees is critical to every organisation's success. The fierce competition for top talents demands companies to constantly assess employer attractiveness. Offering competitive wages, family-friendly working conditions or development benefits are classic ways to attract talents (e.g. Chapman et al. 2005). More recently, researchers started to focus on company ethicality as a distinctive feature that may enhance employer attractiveness and motivate job seekers to pursue with a job application (Solomon 2016; Tsai et al. 2014; Vlachos et al. 2013; Wang 2013). However, effects of ethical market signals on job seekers' application behaviour remain poorly understood. Building on research in the fields of advertising, human resource management and information processing we contribute to the existing literature on talent acquisition with a theoretical understanding of how and why different types of ethical market signals (i.e. ethical certifications and ethical eWoM) affect job seekers' job-pursuit intentions.

\section{Theoretical Contributions}

We extend the existing literature on company ethicality and job seeker behaviour in various ways. Our experimental results show that market signals, that indicate a company's ethicality, can effectively increase job seekers' intentions to apply for a job at that company $\left(\mathrm{H}_{1}\right)$. This corroborates previous research findings suggesting that job seekers' perceptions of company ethicality affect job application decisions positively (Greening and Turban 2000; Lin et al. 2012; Tsai et al. 2014; Wang 2013). While previous studies typically employ cross-sectional survey designs and study effects of ethicality perceptions, we manipulate ethical market signals experimentally and therefore offer more definite insights into cause-and-effect relationships between company ethicality and job seeker behaviour.

We also show that positive effects hold ethical market signals that are under the control of a company (i.e. ethical certifications) and those that are not under company control (i.e. ethical eWoM). While authors have demonstrated beneficial effects of ethical certifications in consumption situations (e.g. Bradu et al. 2014; Vecchio and Annunziata 2015), our research confirms their importance in the recruitment context. Moreover, our findings respond to the growing research interest for effects of ethical eWoM on talent attraction (Frasca and Edwards 2017; Rutter et al. 2016). It has been suggested that eWoM may affect individual decision making independent of its valence; hence even neutral ethical eWoM may positively affect job seekers' application decisions (Tang et al. 2014). However, our findings demonstrate that positive, in comparison with neutral, ethical eWoM results in significantly higher intentions to apply $\left(\mathrm{H}_{1 \mathrm{~b}}\right)$. Hence, while the mere existence of ethical eWoM may encourage candidates to apply, positive endorsements of company ethicality by current or previous employees clearly reinforce these effects. Notably, the eWoM providers were in our study unknown to the respondents. Given that perceived 
familiarity with the source of information can enhance conviction (cf., Reichelt et al. 2014), it is conceivable that positive effects of positive ethical eWoM may be even stronger when job seekers are familiar with the providers of ethical eWoM.

Furthermore, we provide theoretical explanations of why ethical certifications and ethical eWoM affect job-pursuit intentions and corroborate these empirically. In particular, we identified three psychological intervening mechanisms based on MacKenzie et al.'s (1986) Dual Mediation Hypothesis and the consideration of job seekers' attitude toward the job advertisement, Signaling Theory (Rynes 1991; Spence 1973) and the consideration of corporate employment image and the Elaboration Likelihood Model (Petty and Cacioppo 1986), which points to the importance of achieving issuerelevant elaboration that can encourage self-referencing in relation to company ethicality.

First, our findings confirm that ethical certifications and ethical eWoM affect job seekers' application intentions through their attitude toward the job advertisement $\left(\mathrm{H}_{2}\right)$. This adds to previous research which has considered effects of ethical information and message recipients' attitude towards the ad foremost in relation to purchasing decisions (Bickart and Ruth 2012). Hence, we extend the existing literature by showing the importance of considering attitude toward the ad as an outcome of different types of ethical market signals in recruitment contexts. Given that our results establish mediation for both ethical certifications and ethical eWoM suggests that applicants consider both types of signals to form attitudes toward the ad, and that effects of one signal may compensate or reinforce effects of the other. Considering attitude toward the ad is important as it is known to affect a variety of positive outcomes, foremost in consumption contexts, such as willingness to pay or customer loyalty (Nagar 2013). Hence, it is conceivable that positive effects of ethical market signals on job seekers' attitude toward a job advertisement extend to other employer-relevant outcomes, such as job satisfaction or employee loyalty.

Second, our results show that both types of ethical market signals increase job-pursuit intentions indirectly through corporate employment image $\left(\mathrm{H}_{3}\right)$. In line with signaling theory, ethical certifications and positive ethical eWoM constitute unique or discrete signals that shape learning processes and that encourage the development of aggregated or abstract associations, corporate employment image in particular. Researchers and practitioners alike should consider that such signalling outcomes may go beyond job seekers' application behaviour, given that corporate employment image is widely recognised as an important correlate of company attractiveness or overall corporate reputation (e.g. Cober et al. 2003; Kim et al. 2011; Lemmink et al. 2003; Tsai and Yang 2010; Turban 2001). Companies that display ethical certifications in job advertisements and that are supported in social media for their good ethical conduct may enjoy long lasting benefits not only for an enhanced corporate employment image, but also for the good overall corporate reputation that these signals build.

Finally, our study points to the importance of considering self-referencing as a third psychological mechanism through which ethical market signals affect job seekers' application behaviour $\left(\mathrm{H}_{4}\right)$. Our findings are consistent with previous research showing that ads that enable self-referencing and that promote feelings of self-image congruity between the ad and the recipient will bias decision making in favour of the advertised product (Kang and Herr 2006; Kahle and Homer 1985; Yoon and Park 2012). Hence, we can conclude that ethical certifications and positive ethical eWoM enable job seekers' self-referencing and allow them to better connect with related job advertisements which ultimately motivates them to pursue with a job application. Our theoretical reasoning and related empirical results therefore corroborate the argument that foremost millennials value ethical companies because of their strive for ethical value congruency (Solomon 2016).

\section{Implications for Business Ethics}

The present study has wider implications for business ethics as it highlights value and means of communicating an organisation's ethicality in attracting talents, but also the ultimate long-term benefits of organisational efforts to operate ethically toward existing employees and other stakeholders in developing a strong employer brand. Whilst societal benefits of business ethics have been discussed in depth, the positive effects for individual organisations have not yet been fully explored. Our findings suggest that an ethical orientation has the potential to result in competitive advantage because it positively influences the relationship with potential future employees. Given that foremost millennials value ethical organisations, this trend can be expected to persist or even increase.

This study is also a testament for stakeholders' integration of different sources that communicate an organisation's ethicality. As these signals can vary in terms of the extent to which they are under organisational control, organisations need to carefully examine their practices in relation to ethicality and ensure authentic and credible communication of ethical information. It appears beneficial for organisations to acquire ethical certifications to attract employees. Nonetheless, certifications may be subject to stakeholders' scrutiny as they consult sources of information that are beyond an organisation's control. Despite all, it must be considered that the reasons why stakeholders value the disclosure of ethical features are not yet fully understood; these may involve altruistic motivations related to social benefits just 
as egoistic motivations related to individual benefits such as fewer working hours or better working conditions.

Clearly, business ethics is relevant in the recruitment context; however, as we have demonstrated, ethical characteristics do not only directly influence an organisation's key performance measures, but also affect intermediate measures. Ethical market signals affect recipients' attitudes toward job advertisements, their abstract perceptions of the corporate employment image, as well as their identification with the organisation, all of which explain why company ethicality may consist a long-term competitive advantage.

\section{Managerial Implications}

Businesses need to acknowledge the importance of company ethicality as a driver of highly-qualified candidates' job-pursuit intentions. We recommend that companies should strive to provide ethical signals in an authentic and credible way given that job seekers consider both, company-controlled and non-company-controlled sources of information and discrepancies between the two may generate confusions or distrust. As such, businesses are advised to acquire ethical certifications from independent trustworthy organisations. As part of job advertisements, such certifications can effectively enhance job seekers' pursuit intentions as our results clearly indicate. Moreover, given that job seekers increasingly use social media networking sites as a source of information about potential future employers, companies should be alerted about the impact of ethical eWoM provisions.

The internal marketing literature indicates some strategies about how positive ethical eWoM can be encouraged, and how ethical certification be obtained. Internal marketing is related to several positive outcomes such as job satisfaction and commitment, because it addresses employees' needs and values, and allows for an employee-centred view (Shiu and Yu 2010). Specifically, internal marketing does not only directly affect organisational commitment, the relationship is partially mediated by job involvement and job satisfaction (Ting 2011). Organisational commitment is related to the provision of positive WoM because employees with a strong organisational attachment recommend their organisation more likely to other stakeholders, including job applicants (Paulin et al. 2006). Similarly, research in related domains has supported that identification, satisfaction and commitment can be understood as antecedents of positive WoM (Brown et al. 2005). Hence, companies may encourage current or past employees to talk positively about the company's ethicality. At the same time, internal marketing can also help organisations to obtain ethical certifications given that certifications such as for example B Corporation (2017), evaluate the companies for their impact on employees, including job satisfaction. Thus, organisations should acknowledge the importance of internal marketing in order to obtain ethical certifications which are relevant for talent attraction.

Finally, businesses should be aware that the influence of ethical market signals is subject to underlying mediating mechanisms. The implication that follows is that companies can benefit from controlling these mediator variables, for example by conducting periodic checks of attitude toward the ad, corporate employment image and self-referencing in relation to their job advertisements; all three mediator variables can serve as indicators to effectively predict jobseeker behaviour.

\section{Limitations and Future Research}

Several limitations in our study provide avenues for further research. First, the study focuses on the effects of companycontrolled and non-company-controlled market signals on job seekers' job-pursuit intentions, whilst keeping other characteristics of the job advertisement or the job application context constant. The importance of both types of ethical market signals in relation to other drivers of job-pursuit intention, such as company name, company size, salary and industry field, is therefore subject to future investigations.

Likewise, the influence of ethical market signals on application decisions may depend on individual characteristics such as age, social class, cultural origin or person-organisation fit. Research suggests person-organisation fit as a crucial driver of organisational success. For example, $\mathrm{Yu}$ (2014) shows that job seekers who perceive value congruence during recruitment processes develop positive work expectations which, in turn, have a positive impact on organisational attraction. Similarly, Tsai et al. (2014) show that higher levels of socio-environmental consciousness enhance the impact of Corporate Social Performance on job seekers' job-pursuit intentions. We recommend that future research should detail the moderating role of such individual characteristics, based on the theoretical framework established in this study.

Further work is also required to specify the particular influence of different appearances of ethical market signals. Ethical certifications may be distinguished regarding their prominence, their meaning or the certifying source. In the present study, when an established international scheme certifying the company's ethicality (B Corporation, Ethisphere) was provided, respondents reported a higher willingness to apply for the position. However, it must be acknowledged that both schemes used in our experimental study are wellestablished and provided by recognised independent organisations. Research in the food industry shows that effects of certifications depend on the certifying source (Ortega et al. 2011). Hence, we cannot conclude that ethical certifications per se affect pursuit intentions. The effects may differ for certifications that are provided by less well-recognised 
independent certifying organisations, just as they may differ for certification labels that are issued by the company itself. Future research should take this into account. At the same time, future research should explore differences in elaboration in addition to the observed increase in self-referencing. For example, researchers may consider measuring the time respondents took to looking and processing different types of job advertisements. This would allow for a stronger test of our hypotheses, in particular in relation to elaboration.

Similarly, different operationalisations of ethical eWoM should be tested (for example in terms of the degree of positivity). Moreover, given the growing reports of greenwashing incidents, the effects of negative ethical eWoM deserve particular attention in comparison with companycontrolled signals. Relatedly, future research should also consider the relationship between the provider of ethical eWoM and the recipient (e.g. in terms of perceived similarity).

Finally, an important issue for future research is the reason why applicants value ethical market signals. Whilst ethical signals can be important due to disclosing ethical features of the company (e.g. gender equality, hiring applicants with disabilities), they may also be perceived as an indicator of wider company characteristics such as overall company performance and career development opportunities.
Funding There is no funding to declare.

\section{Compliance with Ethical Standards}

Conflict of interest All authors declare that they have no conflict of interest.

Ethical Approval All procedures performed in this study were in accordance with the institution's ethical standards, and with the 1964 Helsinki declaration and its later amendments or comparable ethical standards. The study was peer reviewed and approved by the relevant university ethics committee. Participation in the online survey was voluntary, and all responses were treated anonymously. Respondents were informed of the purpose and anonymity of the study at the beginning of the survey. Informed consent was implied by the returning of a completed questionnaire by respective respondents.

Open Access This article is distributed under the terms of the Creative Commons Attribution 4.0 International License (http://creativeco mmons.org/licenses/by/4.0/), which permits unrestricted use, distribution, and reproduction in any medium, provided you give appropriate credit to the original author(s) and the source, provide a link to the Creative Commons license, and indicate if changes were made.

\section{Appendix 1}

Table 3 Scales 


\section{Appendix 2}

Table 4 Descriptives and correlations among pooled data

\begin{tabular}{|c|c|c|c|c|c|c|c|c|}
\hline & Mean & SD & Cronbach's alpha & Certificates & eWoM & $\begin{array}{l}\text { Attitude } \\
\text { toward the } \\
\text { ad }\end{array}$ & $\begin{array}{l}\text { Corporate } \\
\text { employment } \\
\text { image }\end{array}$ & Self-referencing \\
\hline Attitude toward the ad & 5.55 & 1.18 & 0.946 & 0.113 & 0.284 & & & \\
\hline Corporate employment image & 5.19 & 1.15 & 0.947 & 0.179 & 0.344 & 0.643 & & \\
\hline Self-referencing & 4.62 & 1.30 & 0.929 & 0.132 & 0.239 & 0.560 & 0.639 & \\
\hline Job-pursuit intention & 4.79 & 1.53 & 0.962 & 0.116 & 0.226 & 0.623 & 0.669 & 0.786 \\
\hline
\end{tabular}

\section{Appendix 3}

Table 5 Models M0 and M1 for the three mediators

\begin{tabular}{|c|c|c|c|c|c|c|c|c|c|}
\hline \multirow{2}{*}{$\begin{array}{l}\text { DV: } \\
\text { Model }\end{array}$} & \multicolumn{3}{|c|}{ Ad attitude } & \multicolumn{3}{|c|}{ Corp. emp. image } & \multicolumn{3}{|c|}{ Self-referencing } \\
\hline & M0 & M1 & SE & M0 & M1 & SE & M0 & M1 & SE \\
\hline Intercept & 5.55 & 5.55 & 0.0585 & 5.19 & 5.19 & 0.0568 & 4.62 & 4.62 & 0.0689 \\
\hline Certificates (L2) & & $0.13 *$ & 0.0585 & & $0.20 * * *$ & 0.0568 & & $0.17 *$ & 0.0689 \\
\hline eWoM (L1) & & $0.33 * * *$ & 0.0370 & & $0.39 * * *$ & 0.0319 & & $0.31 * *$ & 0.0347 \\
\hline Cert. $\times$ eWoM $(\mathrm{L} 2 \times \mathrm{L} 1)$ & & 0.03 & 0.0370 & & -0.05 & 0.0319 & & -0.03 & 0.0347 \\
\hline Var bSs & 0.46 & 0.54 & & 0.47 & 0.54 & & 0.87 & 0.94 & \\
\hline Var wSs & 0.95 & 0.73 & & 0.85 & 0.58 & & 0.83 & 0.64 & \\
\hline ICC & $32 \%$ & & & $35 \%$ & & & $51 \%$ & & \\
\hline AIC & 1658 & 1594 & & 1622 & 1501 & & 1710 & 1646 & \\
\hline BIC & 1667 & 1603 & & 1631 & 1509 & & 1719 & 1655 & \\
\hline
\end{tabular}

Raw b coefficient standard errors are reported; Variance between subjects (bSs) and within subjects (wSs) in M0 allow to calculate the intra class correlation ICC. AIC and BIC assess global misfit; the smaller the value, the better the model fit

$* * * p_{2 \mathrm{t}}<0.001, * * p_{2 \mathrm{t}}<0.01,{ }^{*} p_{2 \mathrm{t}}<0.05$

\section{Appendix 4}

See Table 6.

Table 6 Means for DV and mediators

\begin{tabular}{llllll}
\hline IV1 & IV2 & $\begin{array}{l}\text { Job-pursuit } \\
\text { intention }\end{array}$ & $\begin{array}{l}\text { Attitude } \\
\text { toward the } \\
\text { ad }\end{array}$ & $\begin{array}{l}\text { Corporate } \\
\text { employment } \\
\text { image }\end{array}$ & Self-referencing \\
\hline Without certificate & Neutral & 4.25 & 5.11 & 4.54 & 4.10 \\
& Positive eWoM & 4.97 & 5.72 & 5.43 & 4.79 \\
With certificate & Neutral & 4.64 & 5.32 & 5.05 & 4.51 \\
& Positive eWoM & 5.30 & 6.04 & 5.74 & 5.07 \\
\hline
\end{tabular}




\section{References}

Aiken, K. D., \& Boush, D. M. (2006). Trustmarks, objective-source ratings, and implied investments in advertising: Investigating online trust and the context-specific nature of internet signals. Journal of the Academy of Marketing Science, 34(3), 308-323.

Al-Tuwaijri, S. A., Christensen, T. E., \& Hughes, K. E. (2004). The relations among environmental disclosure, environmental performance, and economic performance: A simultaneous equations approach. Accounting, Organizations and Society, 29(5-6), 447-471.

Baron, R. M., \& Kenny, D. A. (1986). The moderator-mediator variable distinction in social psychological research: Conceptual, strategic, and statistical considerations. Journal of Personality and Social Psychology, 51(6), 1173-1182.

Bi, S., Liu, Z., \& Usman, K. (2017). The influence of online information on investing decisions of reward-based crowdfunding. Journal of Business Research, 71, 10-18.

Bickart, B. A., \& Ruth, J. A. (2012). Green eco-seals and advertising persuasion. Journal of Advertising, 41(4), 51-67.

Bradu, C., Orquin, J. L., \& Thogersen, J. (2014). The mediated influence of a traceability label on consumer's willingness to buy the labelled product. Journal of Business Ethics, 124(2), 283-295.

Brown, T. J., Barry, T. E., Dacin, P. A., \& Gunst, R. F. (2005). Spreading the word: Investigating antecedents of consumers' positive word-of-mouth intentions and behaviors in a retailing context. Journal of the Academy of Marketing Science, 33(2), $123-138$

Burnkrant, R. E., \& Unnava, H. R. (1989). Self-referencing: A strategy for increasing processing of message content. Personality and Social Psychology Bulletin, 15(4), 628-638.

Celani, A., \& Singh, P. (2011). Signaling theory and applicant attraction outcomes. Personnel Review, 40(2), 222-238.

Chapman, D. S., Uggerslev, K. L., Carroll, S. A., Piasentin, K. A., \& Jones, D. A. (2005). Applicant attraction to organizations and job choice: A meta-analytic review of the correlates of recruiting outcomes. Journal of Applied Psychology, 90(5), 928-944.

Cheung, M. K., \& Thadani, D. R. (2012). The impact of electronic word-of-mouth communication: A literature analysis and integrative model. Decision Support Systems, 54(1), 461-470.

Cober, R. T., Brown, D. J., Levy, P. E., Cober, A. B., \& Keeping, L. M. (2003). Organizational web sites: Web site content and style as determinants of organizational attraction. International Journal of Selection and Assessment, 11(2/3), 158-169.

Corporation, B. (2017). What are B Corps? Retrieved May 28, 2017 from http://bcorporation.uk/what-are-b-corps-uk.

Disability Confident (2018). Disability confident. Retrieved May 15, 2018 from https://disabilityconfident.campaign.gov.uk.

Eberle, D., Berens, G., \& Ting, L. (2013). The impact of interactive corporate social responsibility communication on corporate reputation. Journal of Business Ethics, 118(4), 731-746.

ECU (2018). Athena SWAN Charter. Retrieved May 15, 2018 from https://www.ecu.ac.uk/equality-charters/athena-swan/.

Ethisphere (2017). 2016 World's most ethical companies. Retrieved May 28, 2017 from https://ethisphere.com/ethisphere-announcesthe-2016-worlds-most-ethical-companies-celebrating-10-years.

Frasca, K. J., \& Edwards, M. R. (2017). Web-based corporate, social and video recruitment media: Effects of media richness and source credibility on organizational attraction. International Journal of Selection and Assessment, 25(2), 125-137.

Goldsmith, R. E., Lafferty, B. A., \& Newell, S. J. (2000). The impact of corporate credibility and celebrity credibility on consumer reaction to advertisements and brands. Journal of Advertising, 24(3), 43-54.
Greening, D. W., \& Turban, D. B. (2000). Corporate social performance as a competitive advantage in attracting a quality workforce. Business and Society, 39(1), 254-280.

Jenkin, M. (2015). Millennials want to work for employers committed to values and ethics. The Guardian. Retrieved May, 11, 2018 from https://www.theguardian.com/sustainable-business/2015/may/05/ millennials-employment-employers-values-ethics-jobs.

Kahle, L. R., \& Homer, P. M. (1985). Physical attractiveness of the celebrity endorser: A social adaptation perspective. Journal of Consumer Research, 11(4), 954-961.

Kang, Y.-S., \& Herr, P. M. (2006). Beauty and the beholder: Toward an integrative model of communication source effect. Journal of Consumer Research, 33(1), 123-130.

Kim, K. H., Jeon, B. Y., Jung, H. S., Lu, W., \& Jones, J. (2011). Effective employment brand equity through sustainable competitive advantage, marketing strategy, and corporate image. Journal of Business Research, 65(11), 1612-1617.

Kirmani, A., \& Rao, A. (2000). No pain no gain: A critical review of literature on signaling unobservable product quality. Journal of Marketing, 64(2), 66-79.

Layton, B. D., \& Insko, C. A. (1974). Anticipated interaction and the similarity-attraction effect. Sociometry, 37(2), 149-162.

Lee, K., Oh, W. Y., \& Kim, N. (2013). Social media for socially responsible firms: Analysis of Fortune 500's Twitter profiles and their CSR/CSIR ratings. Journal of Business Ethics, 118(4), 791-806.

Lemmink, J., Schuijf, A., \& Streukens, S. (2003). The role of corporate image and company employment image in explaining application intentions. Journal of Economic Psychology, 24(1), 1-15.

Lin, C. P., Tsai, Y. H., Joe, S. W., \& Chiu, C. K. (2012). Modeling the relationship among perceived corporate citizenship, firms' attractiveness, and career success expectation. Journal of Business Ethics, 105(1), 83-93.

MacKenzie, S. B., Lutz, R. J., \& Belch, G. E. (1986). The role of attitude toward the ad as a mediator of advertising effectiveness: A test of competing explanations. Journal of Marketing Research, 23(2), 130-143.

Martin, B. A. S., Lee, C. K.-C., \& Yang, F. (2004). The influence of ad model ethnicity and self-referencing on attitudes. Evidence from New Zealand. Journal of Advertising, 33(4), 27-37.

Melanthiou, Y., Pavlou, F., \& Constantinou, E. (2015). The use of social network sites as an e-recruitment tool. Journal of Transnational Management, 20(1), 31-49.

Nagar, K. (2013). An empirical investigation into the influence of green advertising on brand loyalty. Journal of Service Research, 13(2), 71-94.

Ortega, D. L., Wang, H. H., Wu, L., \& Olynk, N. J. (2011). Modeling heterogeneity in consumer preferences for select food safety attributes in China. Food Policy, 36(2), 318-324.

Osburg, V.-S., Strack, M., Conroy, D. M., \& Toporowski, W. (2017). Unveiling ethical product features: The importance of an elaborated information presentation. Journal of Cleaner Production, $162,1582-1591$.

Paulin, M., Ferguson, R. J., \& Bergeron, J. (2006). Service climate and organizational commitment: The importance of customer linkages. Journal of Business Research, 59(8), 906-915.

Petty, R. E., \& Cacioppo, J. T. (1986). Communication and persuasion: Central and peripheral routes to attitude change. New York: Springer.

Reichelt, J., Sievert, J., \& Jacob, F. (2014). How credibility affects eWoM reading: The influences of expertise, trustworthiness, and similarity on utilitarian and social functions. Journal of Marketing Communications, 20(1-2), 65-81.

Riordan, C. M., Gatewood, R. D., \& Bill, J. B. (1997). Corporate image: Employee reactions and implications for managing corporate social performance. Journal of Business Ethics, 16(4), 401-412. 
Rutter, R., Roper, S., \& Lettice, F. (2016). Social media interaction, the university brand and recruitment performance. Journal of Business Research, 69(8), 3096-3104.

Rynes, S. L. (1991). Recruitment, job choice, and post-hire consequences: A call for new research directions. In M. Dunnette \& L. Hough (Eds.), Handbook of industrial/organizational psychology (Vol (2, pp. 399-444). Palo Alto: Consulting Psychologists Press.

Shiu, Y.-M., \& Yu, T.-W. (2010). Internal marketing, organisational culture, job satisfaction, and organisational performance in nonlife insurance. The Service Industries Journal, 30(6), 793-809.

Solomon, M. (2016). You've got millennial employees all wrong; Here are the four things you need to know now. Forbes. Retrieved May 14, 2018 from https://www.forbes.com/sites/micahsolom on/2016/01/26/everything-youve-heard-about-millennial-emplo yees-is-baloney-heres-the-truth-and-how-to-use-it/\#e0139dd490 46.

Spence, M. (1973). Job market signaling. Quarterly Journal of Economics, 87(3), 355-374.

Srivastava, J. N., \& Lurie, L. (2001). A consumer perspective on pricematching refund policies: Effect on price perceptions and search behaviour. Journal of Consumer Research, 28(2), 296-307.

Stewart, R., Volpone, S. D., \& Avery, D. R. (2011). You support diversity, but are you ethical? Examining the interactive effects of diversity and ethical climate. Journal of Business Ethics, 99(3), 581-593.

Tang, T., Fang, E., \& Wang, F. (2014). Is neutral really neutral? The effects of neutral user-generated content on product sales. Journal of Marketing, 78(4), 41-58.

Ting, S.-C. (2011). The effect of internal marketing on organizational commitment: Job involvement and job satisfaction as mediators. Educational Administration Quarterly, 47(2), 353-382.

Tsai, W.-C., \& Yang, I. W.-F. (2010). Does image matter to different job applicants? The influences of corporate image and applicant individual differences on organizational attractiveness. International Journal of Selection and Assessment, 18(1), 48-63.
Tsai, Y.-H., Joe, S.-W., Lin, C.-P., \& Wang, R.-T. (2014). Modeling job pursuit intention: Moderating mechanisms of socio-environmental consciousness. Journal of Business Ethics, 125(2), 287-298.

Turban, D. B. (2001). Organizational attractiveness as an employer on college campuses: An examination of the applicant population. Journal of Vocational Behavior, 58(2), 293-312.

Vecchio, R., \& Annunziata, A. (2015). Willingness-to-pay for sustainability-labelled chocolate: an experimental auction approach. Journal of Cleaner Production, 86, 335-342.

Vlachos, P. A., Panagopoulos, N. G., \& Rapp, A. A. (2013). Feeling good by doing good: Employee CSR-induced attributions, job satisfaction, and the role of charismatic leadership. Journal of Business Ethics, 118(3), 577-588.

Wang, R.-T. (2013). Modeling corporate social performance and job pursuit intention: Mediating mechanisms of corporate reputation and job advancement prospects. Journal of Business Ethics, 117(3), 569-582.

Wheeler, S. C., Petty, R. E., \& Bizer, G. Y. (2005). Self-schema matching and attitude change: Situational and dispositional determinants of message elaboration. Journal of Consumer Research, 31(4), 787-797.

Yoon, S.-J., \& Park, J. E. (2012). Do sensory ad appeals influence brand attitude? Journal of Business Research, 65(11), 1534-1542.

Yu, K. Y. T. (2014). Person-organization fit effects on organizational attraction: A test of an expectations-based model. Organizational Behavior and Human Decision Process, 124(1), 75-94.

Zerbini, F. (2017). CSR initiatives as market signals: A review and research agenda. Journal of Business Ethics, 146(1), 1-23.

Zhang, Z., Zyphur, M. J., \& Preacher, K. J. (2009). Testing multilevel mediation using hierarchical linear models: Problems and solutions. Organizational Research Methods, 12(4), 695-719.

Zhao, X., Lynch, J. G. Jr., \& Chen, Q. (2010). Reconsidering Baron and Kenny: Myths and truths about mediation analysis. Journal of Consumer Research, 37(2), 197-206. 